\title{
Reexamining the Democratic Party in the Implementation of Indonesia's General Elections
}

\author{
Dedi Kusuma Habibie ${ }^{1}$, Herdin Arie Saputra ${ }^{2 *}$, Sanny Nofrima ${ }^{3}$, Dafrin Muksin 4 \\ 1Department of Public Administration, Faculty of Social and Political Siences, Universitas Riau \\ Bina Widya Campus, Km 12, 5 Simpang Baru, Pekanbaru 28293, Indonesia \\ 2,3,4,Master of Government Studies, Universitas Muhammadiyah Yogyakarta \\ Jl. Brawijaya, Bantul, Daerah Istimewa Yogyakarta 55183, Indonesia
}

*Correspondingauthor: herdinariesaputra@gmail.com

\begin{abstract}
Direct elections (Pilkada) are part of democracy; it shows a clear orientation, where the positioning and interests of the people are at the highest level in politics so far. This study aims to analyze some of the main problems in the implementation of regional elections in Indonesia. This type of research used in this research is qualitative research. Analyzes were performed using the Nvivo 12 plus software. In data collection, this research was conducted through literature studies or focused on secondary data in journals and wellknown online media news. The result of this research is that the direct regional election cannot be separated from various problems, such as the size of political capital, the weak role of political parties, the existence of interests, oligarchs, political dynasties, money politics, and intimidation of state civil servants (ASN). Pilkada immediately seemed to be dominated by elite groups with established modalities not to provide public space to participate.
\end{abstract}

\section{Article Info : \\ Article History: \\ Received: December 21, 2020 \\ Revised : February 24, 2021 \\ Accepted : March 29, 2021 \\ Keywords: \\ democracy; evaluation; regional elections; indonesia}

\section{INTRODUCTION}

General elections are the ground of democracy and a political foundation for countries to create a better future. The pillar of democracy directs the country to achieve democracy and build a developed civilization. Elections are also a significant momentum for a regime to realize the ideals of its country. The implementation of democracy cannot be separated from the process of holding general elections. Democratic values that must continuously be developed include freedom, autonomy, equality, representation, and majority rule citizenship (Chaniago, 2016). After the amendments to the 1945 Constitution, Law no. 22 of 1999 replaced by Law no. 32 of 2004 concerning local government. The regional head is elected directly by the peoplea nd has a responsibility to the people. It is to improve the existing democratic system in Indonesia (Frensiska, 2015). 
The concept of autonomy adopted by Indonesia provides policies for each region in order to be able to carryout regional headel ections and determine their respective governments. In the law, Regional Election has not been included in the general election (Pemilu) section. On June 1, 2005, the first Pilkada washeld, which took place in East Kalimantan Province, Kutai Kartanegara Regency. Since the passing of Law no. 22 of 2007 concerning General election organizers, the regional election has become part of the election. In Indonesia, regional elections are a direct mandate of there form movement in 1998. In this case, the importance of participation from the community to be directly involved in the election ofl eaders, therefore regional heade lections, canbeanessentialopportunity in thenationandstate'sdevelopment (Suyatno, 2016). Ethical values are needed in building an electoral system. The various theories that we have obtained and have had experience in Indonesia'spolitics sofar can be used as capital to build democracy by prioritizing the principles of values that we share in common belief. Withoute thics, power will be weak because there is no legitimacy; withtheexistenceofethics, powercanbecontrolled (Ma'riyah, 2012).

The direct regional election is considered a basic form of restoring people's fundamental rights in the regions by giving full authority to recruit regional heads to revive democratic life at the local level (Suparno, 2018). In direct elections, people in the regions can make direct choices regarding candidates. The direct regional elections' success to create a democratic regional leadership, following the people's short comings and demands. In the context of strengthening democracy, the direct election became a pillar that strengthened the building of democracy nationally. His system has resulted in dynamic conditions in a society that has given rise to the euphoria of political democracy every where; then, chaos has impacted various polemics in the regions. It is unfortunate that the euphoria of democracy should have created a conducive atmosphere due to an electoral system based on democracy but is not matching substance.

The direct election system causes high election costsand high levels of corruption and increases political tension These problems range from the costs of organizing the elections, which require high costs, the rise of money politics which causes the potential for corruption of elected regional heads, the high potential for conflict in the social system of society, legal suspicions, to symptoms of the outbreak of dynastic political practices. Elections are not only about piercing pictures or choosing images but choosing the best ones, bringing about a change in the direction of the growth of the nation and state (Hendrayanto, 2008). Money politics in the 2015 postconflict local election in Simpasai Village, Lambu District, Bima Regency in the form of distribution of assistance through social assistance carried out by election participants in the form of money, in the form of materials, in the form of goods, and the form of necessities (Maemunah \& Masita, 2016). The strategies for donating to voters vary widely, such as cash, organizational assistance, and infrastructure assistance (Saputro, 2018).

The factors that cause money politics in society are the community's economic limitations, the limitations of the community's economy, the low quality of public education, and weak supervision. The money politics process is carried out directly by specific political candidates or competitors. Indirectly through other parties in the

46| Journal of Local Government Issues (LOGOS), 4 (1), March 2021, pp $45-59$ ISSN : 2620-8091 print | 2620-3812 online 
provision and application of Politics In intermediaries, the influence of money and political practices can damage democratic order and bring other new problems to the government, creating images and detrimental impacts in the long term (Fitriani, Karyadi, \& Chaniago, 2019). The open proportional system fostered money politics, as candidates were forced to contest candidates from political parties for an individual vote. Then, since the party's seats are allocated to the candidate with the most votes, they only need "a few" votes to beat their opponent in the party. Money politics is a mechanism for differentiating legislative candidates to provide more value to voters than internal competitors (Muhtadi, 2019). Money in politics contributes to corruption in Malaysia. Various types of corruption in the country were identified as political contributions, bribery and money politics; those are the evidence of the factors underlying money politics (Azmi \& Zainudin, 2020).

The pattern is more complex and involves more actors between candidates and voters, and election administrators. The case study is used to see the pattern of money politics in the legislative elections in Surabaya and Sidoarjo in the 2014 Election. The relationship between the emergence of pragmatic-rational voters, party oligarchs' involvement in moving the political party machine, and covert transactions with election organizers (Aminuddin \& Attamimi, 2019). The root of money politics is that candidates and people with capitalist behavior are based on economic gain and loss. At the same time, legal loopholes, weak supervision, and a proportional electoral system open opportunities for money politics development (Delmana, 2020).

Kedungjati Village people receive money politics based on rational goal behavior. People consider money politics as tradition. Kedungjati Village people will come to the polling station with money given by candidates. People accept money politic because people think that rejecting wealth is not a good thing. From the beginning, the community knows the motivation and objectives of the candidates. However, on the other hand, the community already has its candidate criteria without being forced by money politics (Putri, Arifani, Auliavia, \& Nuriyah, 2020). The electoral system is divided into regional systems, i.e. the electoral system based on regional unity and proportionality, namely, the system in which the People's Representative Agency is allocated to each political party following its representatives' percentage. Voice received by each party. The final factor is the community factor as a participant in the election and voters. The occurrence of money politics and community factors as receiving money and society as donors (election participants) cannot separate the political habits of the community, the economic status of the community, and the low level of political education, lack of understanding of criminal provisions in elections, and ignorance of the nature or purpose of the election (Nabila, Prananingtyas, \& Azhar, 2020). The trigger for the conflict reaction was due to regional sentiment, alleged money politics, the involvement of the country's civil apparatus (ASN), and the absence of C6 forms (notification to voters if their name is included in the Permanent Voters List) (Saputra, Setiawan, Nofrima, \& Muksin, 2021).

Political recruitment by political parties aims to concentrated and informal regional election nominations. The candidates' financial requirements of the selection capacity have been increased through pragmatic consideration, providing more space for candidates with a dynasty background (Fitriyah, 2020). Dynastic politics emerged

47| Journal of Local Government Issues (LOGOS), 4 (1), March 2021, pp 45- 59 ISSN : 2620-8091 print | 2620-3812 online 
because regional leaders at this time could not run for the next election. The ruler at the national level wants to use his power to place his family members as rulers at the regional level. As a result, many regional heads are nominated but cannot afford and are willing to become heads of regions. The ideal dynasty political design can be taken by strengthening the requirements to declare legitimate regional head candidates and prevent prospective regional heads that do not meet formal or legal requirements (Siboy, 2020). The implementation and reform of the North Maluku Dynasty, Regional Autonomy, and decentralization run along. The Abdul Gani Dynasty Kasuba and Ahmad Hidayat Mus's political practices are legalized by strong economic, political, social and cultural models. The political dynasty's practice also recruits candidates by politics or mastering political parties that will take part in regional head elections and legislative elections at the provincial and district/city levels (Muksin, Purwaningsih, \& Nurmandi, 2019). According to the politics of the Islamic dynasty, it is permissible as long as it is based on the leader's condition. It must fulfil the appointment process, exemplified by the Prophet, and the leader of the friend following the people's expectations. People and leaders are experts in their fields. Simultaneously, if leaders are individuals or groups that want, not experts as leaders, and prioritize individuals or groups' interests, and dynasty politics is not allowed (Syafril, 2020).

The reason for the emergence of the party oligarchy, which became the general chairman of the party in the district of Landak 2017 regional election, is 1) Power based on formal political rights; The Central Leadership Council (DPP) is the highest body in party organizations and has the authority to determine and decide candidates for regional heads. Absolute authority; 2) Formal position in the organization; The Central Leadership Council (DPP) has vital and robust legality with legislation, so it is entitled to oversee. 3) Coercivity; The Central Leadership Committee (DPP) has the authority to force the Regional Leadership Committee (DPD) and the Branch Leadership Committee (DPC) to implement decisions and sanctions to the lower level organization that does not comply with party decisions. 4) Mobilize power; The Central Executive Committee (DPP) can mobilize the party structure to implement the policy decided by the Central Executive Committee (DPP) through instructions. 5) Material strength; The Central Leadership Committee (DPP) has many resources, so it can be determined that the nomination affects the party structure at that level (Nge, 2018).

Modalities determine politically successful actors. The personal capital possessed by the perpetrators is the basis of the formation of weak trust. Teguh beliefs are a step for the perpetrators to build community participation (Sirait, Noak, \& Azhar). Through this research, and to contribute to thinking about the general election system (regional head), the review is needed and deeply.

Many researchers in Indonesia have carried out several studies on political dynasties. Martien Herna Susanti (Susanti, 2017) shows that political parties and regulations are the two main factors for continuing political dynasties in Pilkada. In the findings (Djati, 2014), Political parties failing to carry out sustainable political regeneration. The usual model is the use of close and direct relatives such as in Kediri (Bimantara \& Harsasto, 2018) with a pattern of profiling and diaspora to legislative institutions such as in Banten (Sutisna, 2017), Bontang (Akbar \& Purnomo, 2019), Nagan Raya (Syahbandir, Hasan, \& Izwar, 2019) and strategic administrative positions

48| Journal of Local Government Issues (LOGOS), 4 (1), March 2021, pp 45 - 59 ISSN : 2620-8091 print | 2620-3812 online 
in the Bureaucracy as happened in Riau (Darmansyah, Syahrani, \& Harirah, 2020). So it is not surprising if the findings (Prianto, 2016) (Purwaningsih \& Widodo, 2020) of Political dynasties that create oligarchies in political parties in practice hinder good governance practice in the regions.

This article takes an analysis of a different angle. It first placed the presidential family at the centre of political dynasty studies that had never been discussed before. Second, from a methodological perspective, this study records the pattern of Jokowi's political dynasty and public response using the NVivo feature.

\section{METHOD}

The type of research used in this study is qualitative research. According to Creswell, Qualitative Research 2009 means the process of exploring and understanding the meaning of individual or group behavior, describing social problems or humanitarian problems (Sugiyono, 2018). Qualitative research is done by comparing and providing trust in the information obtained (Moleong, 2006). This research was conducted to obtain information from various studies of practical solutions. The analysis used in this paper is descriptive. Descriptive analysis is done using NVivo 12 plus software.

In data collection to support this research, the author uses the following data collection techniques. This research data source includes journal articles, relevant websites in providing news based on interviews with journal articles, and relevant websites in providing news based on interviews with several informants related to direct elections in Indonesia. Nvivo 12 Plus analysis in this study used cross tab analysis, cluster analysis, and text research analysis. Cross tab analysis is used to create and create contingency tables from multivarious frequency distributions presented in the matrix format. In comparison, cluster analysis maps thinking in concepts and propositions based on variables. Furthermore, for analysis of text research to find meaning, words, and context related to indirect electoral research problems.

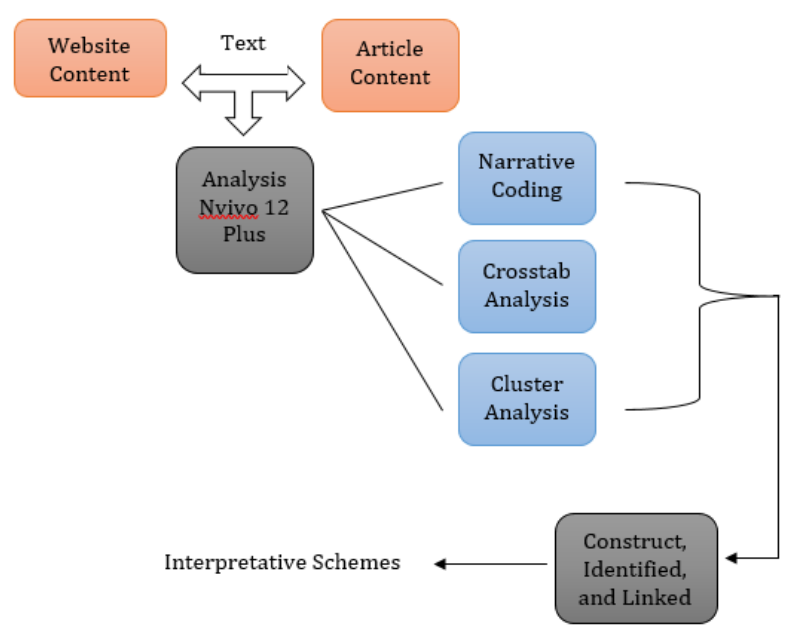

Figure 1. Research Process

Source: processed by the author

49| Journal of Local Government Issues (LOGOS), 4 (1), March 2021, pp $45-59$ ISSN : 2620-8091 print | 2620-3812 online 
The analysis was carried out through three stages, NCapture website: www.Beritasatu.com, www.Bisnis.com, www.CNNIndonesia.com, www.Detik.com, www.Jawapos.com, www.JPNN.com, www.Kompas.com, www.Kumparan.com, www.Liputan6.com, www.MediaIndonesia.com, www.Republika.co.id, www.TimesIndonesia.com, www.Tribunnews.com,and article. The second stage is data analysis with NVivo 12 plus software, reading text and content with similar data, finding interconnected items, finding meanings, words, and contexts interconnected between websites and articles. The third stage is the discourse analysis of the analysis and meaning of website content and articles relevant to direct general elections in Indonesia.

\section{RESULT AND DISCUSSION}

\section{Regional Head Election in Indonesia}

Some regional elections in Indonesia are colored by violent conflict. According to SyamsudinHaris, five things can cause conflict and violence. First, mobilization of mass in the name of the tribe, religion, regional, and offspring. Second, negative campaigns are carried out by candidate pairs. Third, thuggery and political repression are carried out on prospective voters. Fourth, manipulation and law-abiding action. Besides, there are differences in understanding or interpretations on the legal basis used in the implementation of elections. What attracts attention is a pattern formed from the violent conflict in the regional election itself. There are four troubled polling stations, such as in East Java, Buleleng, Tuban, and Depok, conflicts that occur are vertical. The conflicting party has the same level, namely the elite and non-political elite (Rochayati, 2017).

Regulations that govern the elections have not been able to fortify money politics in elections to be minimal. Therefore, with the election bill, it is expected that election regulators can improve the same space for all parties (the principle of equivalent political competition / political equality) to compete in a healthy (Fitriyah, 2012).

A system that causes broad doubts has resulted from several problems such as direct elections that are too expensive, violations and high conflicts, and efforts to encourage strong leaders. Various issues of direct elections are mainly related to gaps in written and unwritten regional election rules. Because the direct selection remains relevant and does not need to be removed and returned to the previous system, the government and the House of Representatives must revise the regional election law due to sound bribes, high costs, and prone to trigger conflict minimized (Fitriyah, 2012). Unframed Government General Policy in the form of "play rules" and adequacy. It gives birth to a series of weaknesses. First, the voter list is uncertain. Second, infrastructure and supervision are inadequate. Third, the delivery of late ballots. Fourth, candidates and psychological supporters are not ready. Fifth, socialization is not optimal. And sixth, an inexperienced General Election Commission (KPU) (Hikmat, 2014).

On the one hand, there are several positive and negative things in every direct election system, the direct election system and indirect elections. They consider the benefits of the two regional head election systems. The direct election has a more significant impact than indirect selection. Some of the benefits included those who

50| Journal of Local Government Issues (LOGOS), 4 (1), March 2021, pp 45- 59 ISSN : 2620-8091 print | 2620-3812 online 
strengthened the sovereignty of the people and avoided injustice in the broader community as part of the government's political and learning aspects. Second, building a law-conscious society and law enforcement that acts decisively and non-partisans creates respect for the leader. In socio-economic, public, and private investor confidence in the system and election results will increase due to important political stability for the economy (Nugraha \& Mulyandari, 2016). Institutional design to accelerate the process of rating democracy in the region. The life of democracy at the local level becomes a practical foundation to realize the multiculturalism spirit needed to realize ethnic harmonization in democratic government (Hanafi, 2016).

The practice of political parties is still far from expectations, such as the process of supporting elitist candidates, poor candidates' recruitment, political parties that are considered only as a vehicle or ticket, to the Abandonia of political parties in the political publication on issues related to political politics and corruption in the regions. Political parties play an essential role in producing candidates for regional heads that have integrity and can carry out the people's mandate through direct elections (Suparno, 2018). The implementation of direct elections in the Papua Province was carried out by following the wishes of the Papuan and indigenous people of Papua, with the mechanism of Noken, where Noken was a means of storing the results of regional voting. The election of regional heads in Papua in the form of bags made of straw, the mechanism of regional head elections is chosen directly by involving voice aspirations that prioritize the voice of the custom head so that indigenous peoples follow the choice of indigenous peoples. Elections with Noken mechanisms are not uncommon for conflicts between tribes or indigenous groups who choose different regional leaders. The fanaticism of the Papuan society is quite strong, especially special, based on the General Chair's opinion (Syamsuryadin, 2016).

Direct elections are part of the democracy carried out in every country of democracy. This shows a clear orientation, where the community's position and interests are at the highest level in politics so far. Regional heads like the governor, the regent/mayor who had previously been elected through the Regional House of Representatives in 2005 carried out the first direct regional head elections. This decision was chosen not suddenly but must be discussed first in its implementation. Nevertheless, many bad records during the periods have been carried out in advance, with enthusiasm in a democratic country. Of course, existing records must be used as evaluation material in carrying out the direct selection in the next period. Some findings must be concerned together to be followed up further, and the findings are also issues from direct elections in the previous period.

\section{The Amount of Capital and Money Politics in The Implementation of Direct Elections}

The amount of capital has become problematic in the implementation of direct elections in each region in Indonesia. The cost of accompanying "political parties" in regional head elections is quite expensive for the regional election contestants. Below, the number of votes per party became a benchmark for political dowry in Indonesia. However, the costs needed are pretty reasonable to support operations in the activities of the candidates. Examples include administrative costs registration, operational

51| Journal of Local Government Issues (LOGOS), 4 (1), March 2021, pp 45- 59 ISSN : 2620-8091 print | 2620-3812 online 
campaign, manufacture of stickers and banners, etc. The source can vary, such as from sympathizers who have no particular interest.

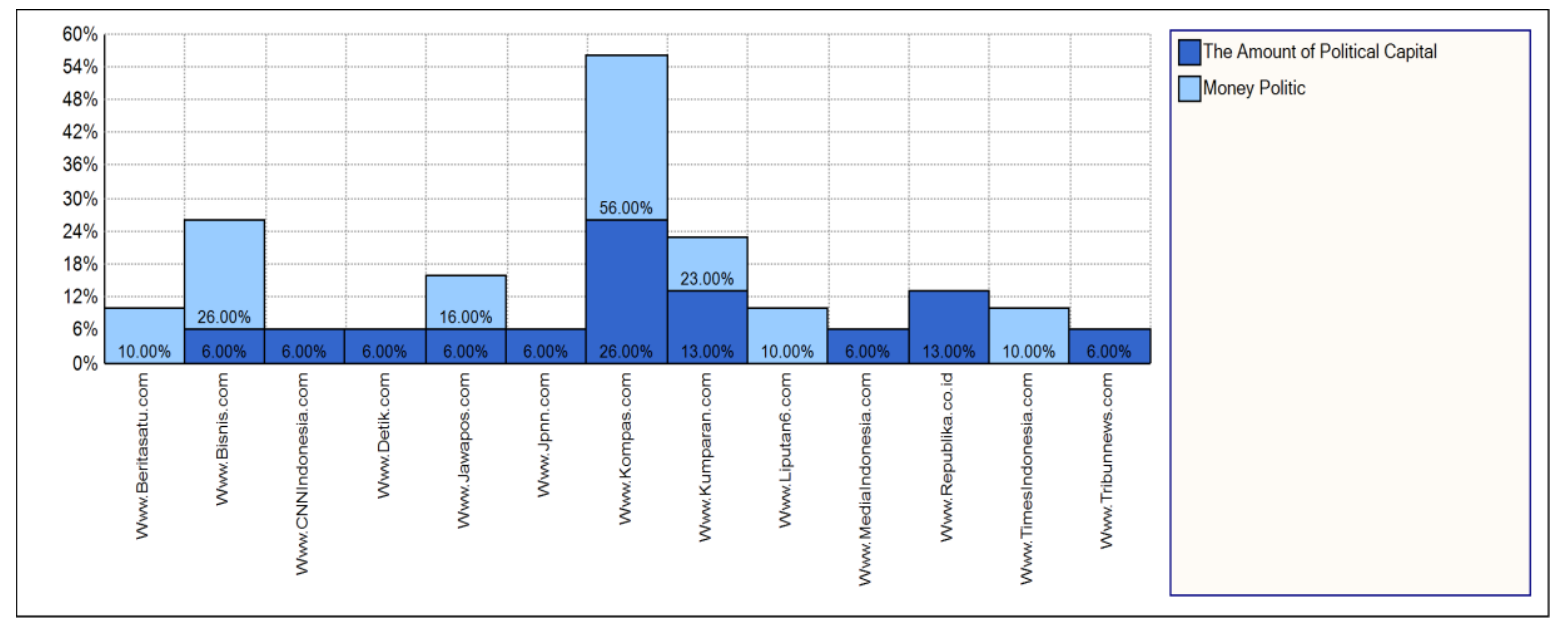

Figure 2. Capital \& Money Politics

Source: processed by the author

Figure 2, the query analysis of Crosstab above shows that the magnitude of capital and political costs is a matter of direct elections today. Of some media sources, one of the weaknesses in the direct regional election in Indonesia is the amount of Cost Capital and Political Money. Money politics can be in the form of cash payments from "success teams" or specific individual candidates given to prospective constituents. Second, donations from candidates to political parties who have supported them or "mandatory contributions" have become a political party term to cadres or candidates who want to run in addition to cash payments for indirect facilities, such as gift distribution, food ingredients for constituents, cement distribution, technology tools, the technology which promises. Even candidates cannot count how much they have spent on official needs (Fitriyah, 2012).

\section{Oligarchy, Political Parties, and Dynasty Politics in The Implementation of Direct Elections}

Oligarchy has played with the community based on family, wealth and military. In general, an oligarchy is a country whose political power is held by a small group of elites. Based on Jeffrey A. Winters theory, oligarchy is distinguished into four types. First, the highest commander, whose form of the oligarch is quite extreme and full of conflict with fellow oligarchs. Second, the collective ruler oligarchy, these oligarchies still play a unique personal role in coercion and violence. Third, the Sultan Oligarchy, the very dominant oligarchy, ruled in all aspects. Fourth, the civilian oligarchy where this oligarchy shares without a monopoly by one party. Furthermore, political parties as a condition in a constitutional law-based democracy can create special tools to fight for value andi deology through the structure of power and power obtained through elections (Bakar, 2016). 


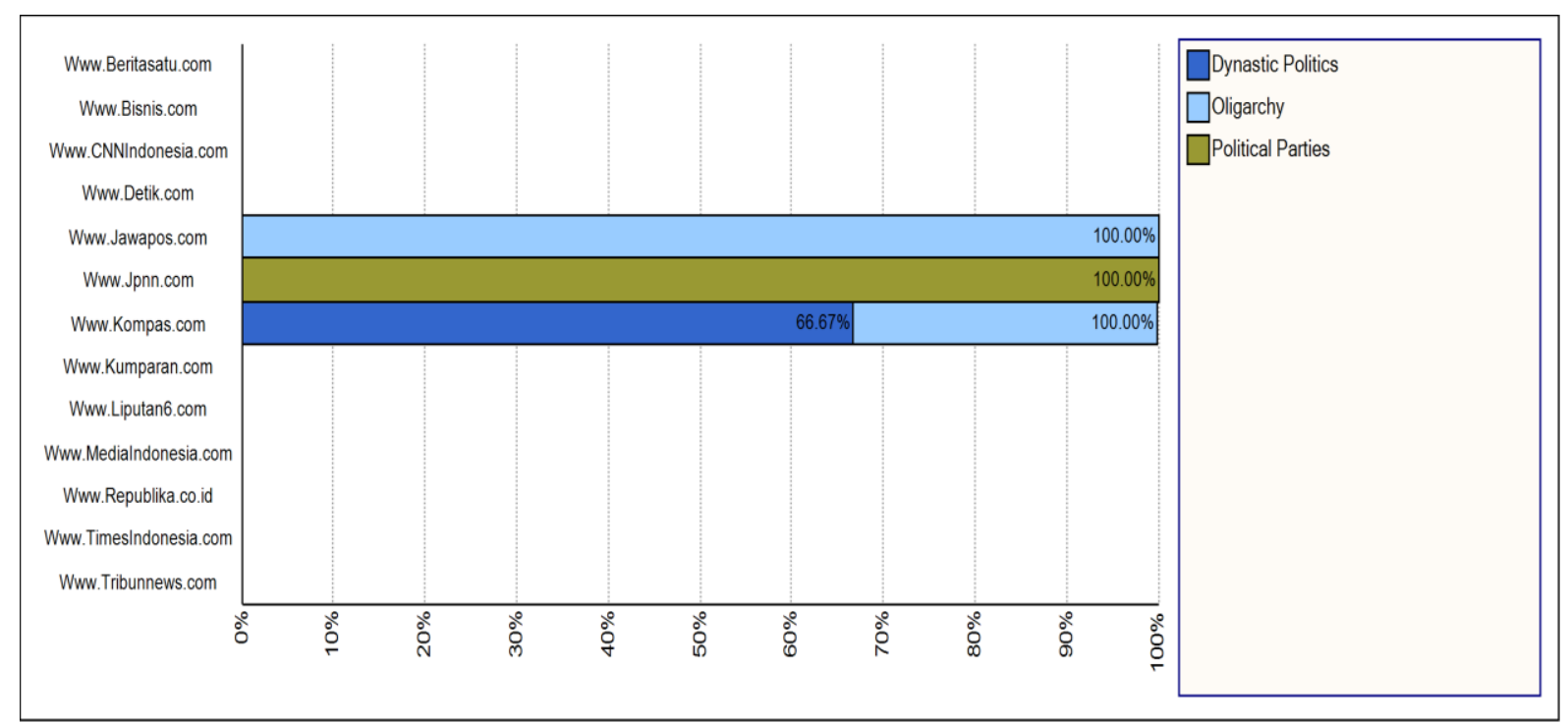

Figure 3. Oligarchy, Dynasty Political \& Political Parties

Source: processed by the author

The tendency to keep family members and relatives in the power network is common place to ensure power remains in the family line. Dynasty politics has become something inherent in Indonesian politics. No wonder ifso meareas often do dynasty politics to maintain power. This patternis in modern western society in the community that imitates the western style (Bimantara \& Harsasto, 2018). If viewed based on Figure 3 Cross tab query analysis above, three things are evaluated in choosing three things that are evaluating in regional head elections directly. Oligarchs in the regions in the regional election are always the motives that harm democracy. Liberalization of political parties to cadres or candidates is not a problem, eventhough cadres or candidates who havebeen convicted of corruption are still considered to be recruited into political parties. The area always presentss mallkings "dynastypolitics" in the direct elections to maintain power. This phenomenon is arguably not a new phenomenon in democracy in Indonesia. This problem must be a concern to find the solutionso that the three problems above do not permanently harm democracy in Indonesia.

\section{Conflict and Corruption in Direct Elections}

At the birth of direct elections, which began in 2005, democratization intends tobuild better. In elections also always gave birth to qualified leaders, it has substantial legitimacy to the community, and always has a clear vision in building and prospering the people. It is to avoid the occurrence of money politics in legislative members and if elected through the Regional House of Representatives. The election departed from the community's expectations to choose a quality leader and bring more prosperous community changes than before. However, there are several obstacles in implementing direct elections in the previous period, such as conflict and the prone to corruption that would occur. 


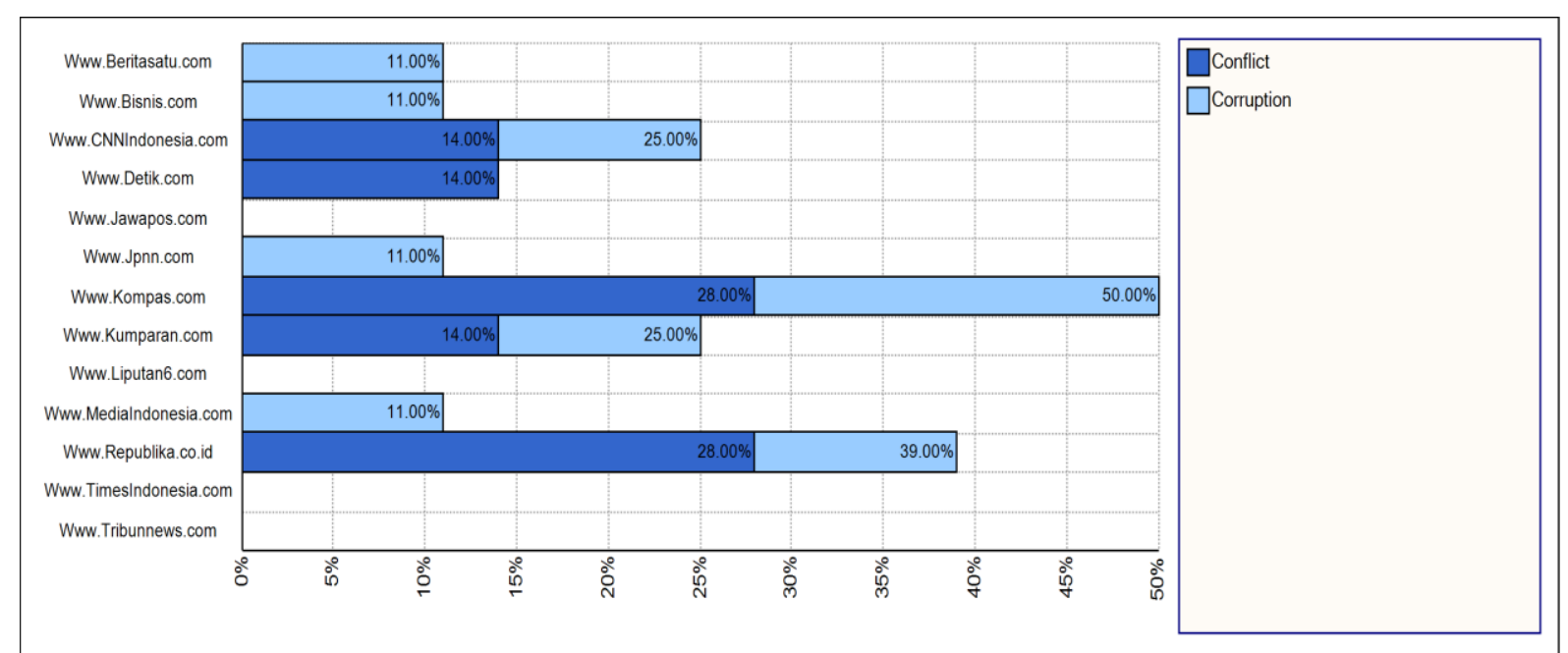

Figure 4. Conflict and Corruption

Source: processed by the author

Figure 4, the above cross tab analysis shows that the media highlights problems such as conflict and vulnerable corruption in the implementation of direct elections. The media conducted interviews with several informants from the executive, legislative and community institutions. In 2019, media such as www.cnnindonesia.com, www.detik.com, www.kompas.com and www.Republika.co.id highlight what often happens in the implementation of direct regional elections, namely conflict. Conflicts that often occur, such as horizontal conflicts tha toccur in the community in the region. Thus, the low level of education and welfare, political and primordial sentiment quickly turned into physical clashes between supporters (Hikmat, 2014). According tootherpress media, such as www.beritasatu.com, www.bisnis.com, www.cnnindonesia.com, www.jpnn.com, www.kompas.com, www.kumparan.com, www.mediaindonesia.com, and www .TimesAindonesia.com said that in the implementation of the regional elections there was a regular frequency carriedout by candidates, such as corruption in several regions that held direct elections. The word corruption can be interpreted as dare devil deeds such as moneyl aundering, bribery receipts. In practice, it consists of three forms: first, acceptance of campaign funds originating from sources prohibited from the law; Second, misuse of facilities and state positions for campaign purposes or destinations (abuse of power); Third, the voice of thepurchase of voters.

\section{Intimidation of State Civil Apparatus (ASN)}

The commencement of a strong government, which then worked to pursue populism with a healthy and firm incremental bureaucracy system, was finally maintained using violence (Alamsyah, 2014) . 


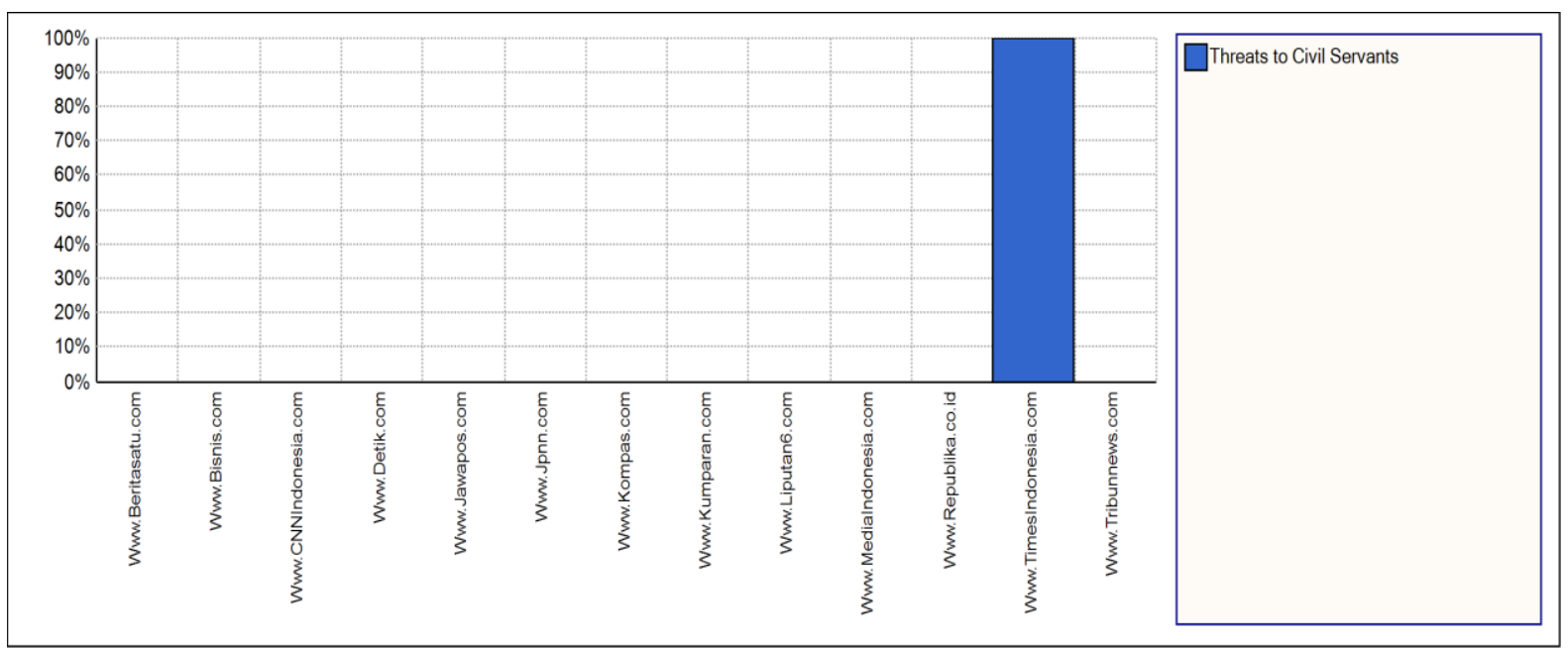

Figure 5. The threat of the country's civil apparatus (ASN)

Source: processed by the author

One form that often occurs is the emphasis of power in government mechanisms that are on going such as threats to each civilian state apparatus (ASN), economic actors to submitto the ruler'spolitical supremacy, and the birth of the Three Thuggery group. In the area like what happened to the phenomenon of bosism in the Philippines. Basedon Figure 5, the above cross-analysis shows that media such as www.timesIndonesia.com stated that every civil servant (ASN) was intimidated by the authorities to electtheruler in the second period to become a regional head. The intimidation of the state civil apparatus is still often found during the organization of the elections. The government's role needs to be strengthened by forming a model of handling comprehensive and neutral violations between institutions to anticipate violations (Sudrajat \& Hartini, 2017). The root of civil servants' neutrality issue lies in the lack of coordination and the application of sanctions (Sudrajat, Hartini, \& Kadarsih, 2014). The law enforcement process is weak. This problem can also be considered the cause of bureaucratic politicization. For civil servants who commit election violations, punishment will not provide a deterrent effect, and a lengthy legal procedure often leads to bureaucratic politicization (Firnas, 2016).

\section{CONCLUSION}

From the description above, it can be concluded that direct electionis a necessity in the democratic system. That is by giving freedom to the public to choose its leader. Because a simple form of democracyis a government-held from the people, for the people, however, direct elections cannot be separated from the problem. Namely: the number of political capital and money, the weak role of political parties, the existence of interests, oligarchs, political dynasties, money politics, and intimidation by the State 
Civil Apparatus (ASN). Legislative and executive general elections immediately seemed dominated by elite groups whose modalities were established to provides pace for the community to participate. Therefore, direct elections need to be evaluated in terms of concept and implementation to realize better governance.

The democratic world has become a practice field for achieving multiculturalism, which is indispensable for realizing national harmony in democratic governance. Transparency, accountability, honesty, and democracy of the system's result are highly expected by the community, shown by the struggle mechanism's capacity to describe the vision, task, and plan promised. It can run a democratic party correctly and follow the goals of democracy. It shows a clear orientation, where the people's position and interests are at the highest level in politics.

\section{REFERENCES}

Akbar, P., \& Purnomo, E. P. (2019). Model Dinasti Politik Di Kota Bontang. JWP (Jurnal Wacana Politik), 4(2), 145-156. http://dx.doi.org/10.24198/jwp.v4i2.25381

Alamsyah, M. N. (2014). Fenomena Electocracy dalam Pilkada Langsung di Indonesia. Academica, 4(1), 761-773.

Aminuddin, M. F., \& Attamimi, N. H. (2019). From Retail to Grocery: Money Politics in 2014 Indonesian Legislative Election. Politik Indonesia: Indonesian Political Science Review, 4(1), 99-120. https://doi.org/10.15294/ipsr.v4i1.12609

Azmi, K. S. A., \& Zainudin, R. (2020). Money in Politics: a Recipe for Corruption in Malaysia. Journal of Financial Crime. https://doi.org/10.1108/JFC-07-2020-0147

Bakar, A. (2016). Politi Dinasti dan Pelembagaan Partai Politik Pengalaman DPC PDIP dan Keluarga Banteng di Kepulauan Selayar. Al Daulah: Jurnal Hukum Pidana dan Ketatanegaraan, 2(1), 105-119. https://doi.org/10.24252/ad.v2i1.1428

Bimantara, N., \& Harsasto, P. (2018). Analisis politik dinasti di kabupaten kediri. Journal of Politic and Government Studies, 7(04), 201-210. https://ejournal3.undip.ac.id/index.php/jpgs/article/view/21909

Chaniago, P. S. (2016). Evaluasi Pilkada Pelaksanaan Pilkada Serentak Tahun 2015. Politik Indonesia: Indonesian Political Science Review, 1(2), 196-211. https://doi.org/10.15294/jpi.v1i2.6585

Darmansyah, R., Syahrani, S. D., \& Harirah, Z. (2020). Potret Dinasti Politik dalam Pengisian Jabatan Administratif. Journal of Political Issues, 2(1), 34-46. https://doi.org/10.33019/jpi.v2i1.28

Delmana, L. P., Zetra, A., \& Koeswara, H. (2020). Problematika Dan Strategi Penanganan Politik Uang Pemilu Serentak 2019 Di Indonesia. Tata Kelola Pemilu Indonesia, 1(2), 1-20. https://doi.org/10.46874/tkp.v1i2.61

Djati, W. R. (2014). Revivalisme Kekuatan Familisme dalam Demokrasi: Dinasti Politik di Aras Lokal. Masyarakat: Jurnal Sosiologi, 18 (2) 203-231. https://doi.org/10.7454/mjs.v18i2.3726 
Firnas, M. A. (2016). Politik Dan Birokrasi: Masalah Netralitas Birokrasi Di Indonesia Era Reformasi. JRP (Jurnal Review Politik), 6(1), 160-194. Retrieved from http://jurnalfuf.uinsby.ac.id/index.php/JRP/article/view/1125

Fitriani, L. U., Karyadi, L. W., \& Chaniago, D. S. (2019). Fenomena Politik Uang (Money Politic) Pada Pemilihan Calon Anggota Legislatif di Desa Sandik Kecamatan Batu Layar Kabupaten Lombok Barat. RESIPROKAL: Jurnal Riset Sosiologi Progresif Aktual, 1(1), 53-61. https://doi.org/10.29303/resiprokal.v1i1.5

Fitriyah, F. (2020). Partai Politik, Rekrutmen Politik dan Pembentukan Dinasti Politik pada Pemilihan Kepala Daerah (Pilkada). Politika: Jurnal Ilmu Politik, 11(1), 1-17. https://doi.org/10.14710/politika.11.1.2020.1-17

Fitriyah, M. (2012). Fenomena Politik Uang dalam Pilkada. Politika: Jurnal Ilmu Politik, 3(1), 5-14. https://doi.org/10.14710/politika.3.1.2012.5-14

Frensiska, R. (2015). PERUBAHAN SISTEM PEMILIHAN KEPALA DAERAH: Implikasi terhadap Calon Perseorangan dalam Perspektif Hak Asasi Manusia. Jurnal Rechts Vinding: Media Pembinaan Hukum Nasional, 4(1), 105-122. http://dx.doi.org/10.33331/rechtsvinding.v4i1.50

Hanafi, R. I. (2016). Pemilihan Langsung Kepala Daerah di Indonesia: Beberapa Catatan Kritis Untuk Partai Politik. Jurnal Penelitian Politik, 11(2), 1-16. https://doi.org/10.14203/jpp.v11i2.197

Hikmat, M. M. (2014). Pemetaan Masalah dan Solusi Konflik Lokal dalam Pilkada Langsung di Indonesia. MIMBAR: Jurnal Sosial dan Pembangunan, 30(1), 18-27. https://doi.org/10.29313/mimbar.v30i1.437

Kukuh Hendrayanto, M. (2008). Evaluasi Pilkada Langsung (Studi di Komisi Pemilihan Umum di Kabupaten Ngawi). Thesis :University of Muhammadiyah Malang.

Ma'riyah, C. (2012). Menggugat Politik Dinasti Dalam Pemerintahan Indonesia. Jurnal Ilmu Pemerintahan, 36, 1-19.

Maemunah, M., \& Masita, M. (2016). Praktek Politik Uang Pada Pemilukada Serentak 2015 (Studi Kasus di Desa Simpasai Kecamatan Lambu Kabupaten Bima). CIVICUS: Pendidikan-Penelitian-Pengabdian Pendidikan Pancasila dan Kewarganegaraan, 4(1), 21-26. https://doi.org/10.31764/civicus.v4i1.321

Moleong, L. J. (2006). Metodologi Penelitian Kualitatif. Bandung: PT Remaja Rosdakarya.

Muhtadi, B. (2019). Politik uang dan new normal dalam pemilu paska-orde baru. Integritas: $\quad J u r n a l \quad$ Antikorupsi, 55-74. https://doi.org/10.32697/integritas.v5i1.413

Muksin, D., Purwaningsih, T., \& Nurmandi, A. (2019). Praktik Dinasti Politik Di Aras Lokal Pasca Reformasi: Studi Kasus Abdul Gani Kasuba Dan Ahmad Hidayat Mus Pada Pilkada Provinsi Maluku Utara. JWP (Jurnal Wacana Politik), 4(2), 133-144. https://doi.org/10.24198/jwp.v4i2.25336

Nabila, N., Prananingtyas, P., \& Azhar, M. (2020). Pengaruh Money Politic Dalam Pemilihan Anggota Legislatif Terhadap Keberlangsungan Demokrasi Di Indonesia. Notarius, 13(1), 138-153. https://doi.org/10.14710/nts.v13i1.29169

Nge, H. J. (2018). Oligarki Partai Politik dalam Rekrutmen Calon Kepala Daerah. Jurnal Academia Praja, 1(01), 59-84. https://doi.org/10.36859/jap.v1i01.42 
Nugraha, A., \& Mulyandari, A. (2016). Pilkada Langsung Dan Pilkada Tidak Langsung Dalam Perspektif Fikih Siyasah. Mazahib, 15(2), 208-236. https://doi.org/10.21093/mj.v15i2.630

Prianto, B. (2016). Partai Politik, Fenomena Dinasti Politik dalam Pemilihan Kepala Daerah, dan Desentralisasi. Publisia: Jurnal Ilmu Administrasi Publik, 1(2), 105117. https://doi.org/10.26905/pjiap.v1i2.436

Purwaningsih, T., \& Widodo, B. E. C. (2020). The Interplay of Incumbency, Political Dynasty and Corruption in Indonesia: Are Political Dynasties the Cause of Corruption in Indonesia? Revista UNISCI 18 (53), 157-176. https://www.researchgate.net/deref/http\%3A\%2F\%2Fdx.doi.org\%2F10.31439 $\% 2$ FUNISCI-89

Putri, M. I. D., Arifani, N., Auliavia, M. V., \& Nuriyah, S. (2020). Politik dan Tradisi: Politik Uang dalam Pemilihan Kepala Desa. Jurnal ISIP: Jurnal Ilmu Sosial dan Ilmu Politik, 17(2), 72-81. http://dx.doi.org/10.36451/j.isip.v17i2.46

Rochayati, N. (2017). Dinamika Demokrasi Lokal Di Asia Tenggara: Desentralisasi, Pilkada, Dan Konflik Kekerasan di Indonesia Dan Filipina. Global: Jurnal Politik Internasional, 10(2).

Saputra, H. A., Setiawan, A., Nofrima, S., \& Muksin, D. (2021). Political Conflict on the Results of Recapitulation in Regional Head Elections in North Borneo Province in 2015. ARISTO, 1(1), 1-23.

Saputro, D., \& Erni Zuhriyati. (2018). Perkembangan Money Politik Di Pilkada Tahun 2018 di Kabupaten Ponorogo. Prosiding Konferensi Nasional Ke-8 Asosiasi Program Pascasarjana Perguruan Tinggi Muhammadiyah (APPPTMA).

Siboy, A. (2020). Desain Penguatan Kualitas Politik Dinasti dalam Pemilihan Kepala Daerah. Keadilan, 18(2), 142-163. https://dx.doi.org/10.37090/keadilan.v18i2.311

Sirait, M. Z., Noak, P. A., \& Azhar, M. A. (2020). Modalitas Dalam Keterpilihan Kandidat Pada Pemilu Legislatif 2014. E-Jurnal Politika, 1(2), 10-10. https://ojs.unud.ac.id/index.php/politika/article/view/62871

Sudrajat, T., \& Hartini, S. (2017). Rekonstruksi Hukum atas Pola Penanganan Pelanggaran Asas Netralitas Pegawai Negeri Sipil. Mimbar Hukum-Fakultas Hukum Universitas Gadjah Mada, 29(3), 445-460. Retrieved from https://ojs.unud.ac.id/index.php/politika/article/view/62871

Sudrajat, T., Hartini, S., \& Kadarsih, S. (2014). Kebijakan Netralitas Politik Pegawai Negeri Sipil dalam Pemilukada (Studi di Jawa Tengah). Padjadjaran Journal of Law, 1(3), 537-557. https://doi.org/10.22304/pjih.v1n3.a7

Sugiyono, S. (2018). Metode Penelitian Kualitatif untuk Penelitian yang Bersifat: Eksploratif, Enterpretif, Interaktif dan Konstruktif. Bandung: CV. Alfabeta.

Suparno, S. (2018). Pemilihan Kepala Daerah Langsung Kelebihan dan Kekurangannya. Mimbar Administrasi FISIP UNTAG Semarang, 13(18), 1-8.

Susanti, M. H. (2017). Dinasti Politik dalam Pilkada di Indonesia. Journal of Government and Civil Society, 1(2), 111-119. http://dx.doi.org/10.31000/jgcs.v1i2.440

58| Journal of Local Government Issues (LOGOS), 4 (1), March 2021, pp 45- 59 ISSN : 2620-8091 print | 2620-3812 online 
Sutisna, A. (2017). Gejala proliferasi dinasti politik di Banten era kepemimpinan gubernur Ratu Atut Chosiyah. Politik Indonesia: Indonesian Political Science Review, 2(2), 100-120. https://doi.org/10.15294/jpi.v2i2.9329

Suyatno, S. (2016). Pemilihan Kepala Daerah (Pilkada) dan Tantangan Demokrasi Lokal di Indonesia. Politik Indonesia: Indonesian Political Science Review, 1(2), 212-230. https://doi.org/10.15294/jpi.v1i2.6586

Syafril, R. (2020). Politik Dinasti dalam Pandangan Islam. JESS (Journal of Education on Social Science), 4(1), 125-135. https://doi.org/10.24036/jess.v4i1.256

Syahbandir, M., Hasan, E., \& Izwar, I. (2019). A Political Dynasty in Nagan Raya District. Paper presented at the 1st Aceh Global Conference (AGC 2018). https://dx.doi.org/10.2991/agc-18.2019.38

Syamsuryadin. (2016). Pemilihan Kepala Daerah Secara Langsung Dengan Sistem Noken di Papua. Research Reports: Universitas Pancasila 